\title{
PERAMALAN JUMLAH PRODUKSI AIR DENGAN ALGORITMA BACKPROPAGATION
}

\author{
Musli Yanto $^{1)}$, Sitti Rizki Mulyani ${ }^{2)}$ dan Liga Mayola ${ }^{3)}$ \\ ${ }^{1}$ Teknik Informatika, Fakultas Ilmu Komputer,Universitas Putra Indonesia YPTK \\ ${ }^{2}$ Manajemen, Fakultas Ekonomi dan Bisnis,Universitas Putra Indonesia YPTK \\ ${ }^{3}$ Sistem Informasi, Fakultas Ilmu Komputer,Universitas Putra Indonesia YPTK \\ ${ }^{1,2,3}$ Jl.Raya Lubuk Begalung, Padang, 25221 \\ E-mail : musli_yanto@upiyptk.ac.id ${ }^{1)}$, sitti_rizkimulyani@upiyptk.ac.id ${ }^{2)}$, liga_mayola@upiyptk.ac.id ${ }^{3)}$
}

\begin{abstract}
ABSTRAK
Pada masa saat sekarang ini, peramalan sudah menjadi bentuk bahan pertimbangan dalam segala aspek bidang. Kajian dalam jumlah produksi sering kali banyak peneliti mencoba melakukan peramalan guna sebuah proses manajemen. Dalam penelitian ini, penulis menjadikan topik penelitian yang mengkaji peramalan jumlah produksi air. Hal ini sudah banyak para peneliti melakukan penelitian yang membahas kajian prediksi jumlah produksi air dengan menggunakan Jaringan Saraf Tiruan (JST). Pada penelitian ini, penulis juga akan membahas pembahasan mengenai (JST) dengan algoritma backpropagation guna melihat lagi hasil peramalan jumlah prediksi air yang terjadi pada PDAM yang ada di kota Padang. Algoritma ini berkerja untuk melatih dan menguji pola jaringan yang terbentuk dari beberapa variabel yang digunakan dilihat dari aspek penggunaan dan jumlah air yang terjual. Proses pelatihan dan pengujian dilakukan nantinya akan menghasilkan nilai seberapa besarnya akurasi dari sebuah peramalan. Pada peramalan jumlah produksi air dengan algoritma beckpropagation, penulis mendapati Nilai akurasi pada peramalan ini sebesar $99,78 \%$ dan nilai rata-rata kesalahan (Mape) yang didapat sebesar $0.23 \%$, sehingga hasil peramalan yang didapat bisa dijadikan landasan dalam melakukan manajemen jumlah produksi air.
\end{abstract}

Kata Kunci: Peramalan, Jaringan Saraf Tiruan, Backpropagation, Pola, Mape

\section{PENDAHULUAN}

Air merupakan salah satu sumber daya alam yang memiliki fungsi sangat penting dan merupakan komponen yang penting bagi kelangsungan hidup manusia dan mahluk lainnya. Seiring pertumbuhan penduduk, maka jumlah air yang di produksi secara terus menerus menunjukkan peningkatan sejalan dengan peningkatan kebutuhan air bersih di masyarakat. Pada obejek penelitian ini, yang akan dibahas yakni proses manajemen produksi dan peramalan terhadap jumlah air PDAM.

Hasil peramalan akan sangat berguna bagi pihak PDAM pada masa periode berikutnya. Dalam proses peramalan ini, penulis melakukan peramalan dengan menggunakan jaringan saraf tiruan. Jaringan Saraf Tiruan (JST) adalah sistem pemroses informasi yang memiliki karakteristik mirip dengan jaringan saraf biologi / manusia. Salah satu metode yang digunakan adalah prediksi dengan bantuan kecerdasan buatan menggunakan metode Backpropagation.

Backpropagation memiliki tiga layer dalam proses pelatihannya, yaitu input layer, hidden layer dan output layer. Backpropagation ini merupakan perkembangan dari single layer network. Dengan adanya hidden layer pada Backpropagation dapat menyebabkan tingkat error pada Backpropagation lebih kecil dibanding tingkat error pada single layer network. Karena hidden layer pada Backpropagation berfungsi sebagai tempat untuk menyesuaikan bobot, sehingga di dapatkan nilai bobot yang baru yang bisa diarahkan mendekati dengan target output yang diinginkan.

Pada penelitian yang dilakukan oleh Anindita Septiarini dan Nur Sya'baniah (2012), yang mengangkat topik penelitian yang berjudul Sistem Peramalan Jumlah Produksi Air PDAM Samarinda, bahwa Jaringan Saraf Tiruan metode Backpropagation yang diterapkan pada sistem peramalan jumlah produksi air memberikan hasil yang baik. Hal ini ditunjukkan dengan kecocokan output jaringan dengan target yang koefisiensi kolerasi bernilai 0.949 (mendekati 1). Berdasarkan hasil penelitian didapat bahwa jumlah layar tersembunyi sebanyak 80 unit, galat sebesar 0.1 dan konstanta belajar sebesar 0,01 dan teknik pembelajaran traingdx telah memberikan hasil pengujian yang optimal. Berdasarkan hasil penelitian didapat bahwa jumlah layar tersembunyi sebanyak 80 unit, galat sebesar 0.1 dan konstanta belajar sebesar 0,01 dan teknik pembelajaran traingdx telah memberikan hasil pengujian yang optimal.

Dilanjutkan pada penelitian yang pernah dilakukan sebelumnya, penulis mencoba melakukan penelitian toko retail yang ada di Kota Padang. Penelitian ini bertujuan untuk membantu toko retail dalam melakukan peramalan pengadaan barang. Algoritma Backpropagation Neural Network dapat melakukan proses peramalan terhadap pengadaan barang untuk periode waktu selanjutnya pada 
masing-masing barang pada retail tersebut dan pada akhirnya akan bermanfaat bagi para pengelola toko retail. Proses peramalan dimulai dengan menentukan variabel-variabel yang akan dibutuhkan dalam pola jaringan, selanjutnya pola jaringan yang sudah dibentuk akan dilanjutkan pada proses pelatihan jaringan dengan menggunakan algoritma backpropagation (Musli Yanto, dkk, 2018).

Dengan pembahasan dalam peramalan, penelitian yang dilakukan oleh (Dwi Rahayu, dkk, 2018), membahas klasifikasi harga minyak kelapa sawit dengan menggunakan metode Backpropagation. Metode Backpropagation akan memodelkan data harga minyak kelapa 5 bulan sebelumnya untuk menemukan hasil klasifikasi pada bulan ke-6. Hasil klasifikasi yang didapatkan memiliki tingkat akurasi sebesar $69,57 \%$ dengan jumlah neuron hidden sebanyak 50, nilai learning rate seesar 0,1 dan jumlah iterasi maksimal sebanyak 70.000 .

JST akan dapat digunakan dalam hal untuk melakukan proses pencarian atau proses menemukan sesuatu tujuan yangdiinginkan. Kinerja JST itu sendiri adalah melakukan suatu proses pembelajaran dari suatu model yang diinginkan berdasarkan data, kemudian JST yang akan melakukan proses untuk mencari atau menemukan dalam pencocokan pola (Musli Yanto, dkk, 2016).

Dilanjutkan lagi dengan tema penelitian yang sama, ada beberapa penelitian yang sudah dilakukan dengan objek peramalan distribusi air yang terjadi pada PDAM. Penelitian yang dilakukan oleh Daneswara Jauhari, (2016), mengatakan bahwa jaringan syaraf tiruan backpropagation untuk memprediksi jumlah dari distribusi air perbulan berdasarkan jumlah kehilangan air dan jumlah air yang terjual. Pada tahap pelatihan dilakukan pengujian untuk mendapatkan iterasi, learning rate, data latih dan data uji, jumlah node pada lapisan tersembunyi, dan minimum error yang optimal.

Dilanjutkan lagi pada penelitian dengan objek yang sama pada Jaringan Saaraf Tiruan (JST) Backpropagation dalam prediksi dimana jaringan saraf truan mampu memanfaatkan variabel distribusi air PDAM setiap Kecamatan yang ada di kota Malang sebagai masukan serta data pemakaian air bulan berikutnya sebagai target (Irawan (2015).

Berdasarkan penjelasan yang dibahas pada pemaparan sebelumnya, penulis akan melakukan penelitan dalam proses peramalan dalam jumlah produksi. Tujuan dari hasil proses peramalan ini nantinya akan bermaanfaat bagi pihak PDAM dalam menentukan kapasitas dalam mengelola dan memanajemen jumlah produksi air yang tersedia maupun yang akan di produksi.

\section{RUANG LINGKUP}

Dalam penelitian ini permasalahan penelitian ini, penulis membatasi pembasan seputar peramalan diman penulis akan merancang Jaringan Saraf Tiruan dalam melakukan peramalan produksi air dan menghasilkan hasil prediksi akurasi yang tinggi. Sementara yang menjadi tujuan penelitian ini adalah untuk Membangun suatu sistem prediksi dalam memprediksi jumlah produksi air dan diteruskan untuk dibandingkan dengan target yang diharapkan untuk mengetahui jumlah produksi air di periode berikutnya.

Untuk variabel yang digunakan dalam jaringan dalam proses peramalan yakni jumlah volume ait yang digunakan oleh setiap bagian dengan penjabaran dari sambungan pemakaian rumah (X1), Badan sosial, Tempat Ibadah dan Rumah sakit (X2), MCK/Umum (X3), Industri (X4), Instansi Pemerintah (X5).

\section{BAHAN DAN METODE}

Landasan teori yang mendukung dalam pembahasan penelitian diantaranya :

\subsection{Jaringan Saraf Tiruan}

Jaringan Saraf Tiruan (JST) adalah paradigma pengolahan informasi yang terinspirasi oleh sistem saraf secara biologis, seperti proses informasi pada otak manusia. Elemen kunci dari paradigma ini adalah struktur dari sistem pengolahan informasi yang terdiri dari sejumlah besar elemen pemrosesan yang saling berhubungan (neuron), bekerja serentak untuk menyelesaikan masalah tertentu.Cara kerja JST seperti cara kerja manusia, yaitu belajar melalui contoh. Lapisan-lapisan penyusun JST dibagi menjadi 3, yaitu lapisan input (input layer), lapisan tersembunyi (hidden layer), dan lapisan output (Sutojo, T, dkk, 2011).

Jaringan syaraf tiruan dapat melakukan prediksi jumlah permintaan koran diperlukan data latih yang akan digunakan sebagai sumber pelatihan yang selanjutnya diproses pada tahap pengujian dimana bobot awal harus ditentukan, kemudian menentukan iterasi maksimum, menentukan learning rate dan memperoleh nilai MSE (Nabilla Putri Sakinah,2018).

Jaringan Saraf Tiruan (Artificial Neural Network) pada sistem pengiriman di PT.Pos Indonesia yaitu dengan memanfaatkan variabel - variabel yang dapat menyebabkan keterlambatan dan penundaan dalam hal pengiriman. Dengan adanya variabel tersebut nantinya akan dapat kami lakukansebagai acuan dan penentuan bobot tertentu dalam menentukan prediksi pengiriman barang beserta estimasi waktunya (Muhammad Reza dan Suprayogi, 2017).

\subsection{Algoritma Backpropagation}

Backpropagation adalah model JST yang paling banyak digunakan. Topologi khas backpropagation melibatkan tiga lapisan : lapisan input, dimana data diperkenalkan ke jaringan lapisan tersembunyi, tempat data diproses dan output layer, dimana hasil input yang diberikan diproduksi (D. Huang and Z. Wu, 2017). Backpropagation merupakan algoritma pembelajaran yang terawasi dan biasanya digunakan oleh perceptron dengan banyak lapisan untuk mengubah bobot-bobot 
yang terhubung dengan neuron-neuron yang ada pada lapisan tersembunyinya. Algoritme backpropagation menggunakan error output untuk mengubah nilai bobotbobotnya dalam arah mundur (backward). Untuk mendapatkan error ini, tahap perambatan maju (forward propagation) harus dikerjakan terlebih dahulu (Irwansyah, 2015).

Metode ini dapat digunakan untuk melatih kemampuan jaringan dalam memberikanrespon yang benar terhadap pola masukandengan pola yang dipakai selama pelatihan (Nikmah,2014). Lapisan tersembunyi digunakan untuk penyesuaian bobot selama pelatihan. Backpropagation memiliki ciri yang unik yaitu setelah di lakukan propagasi maju akan dilakukan propagasi mundur untuk melakukan perbaikan bobot, kemudian dilakukan perubahan bobot, proses ini dilakukan terus menerus sampai mencapai batas iterasi atau minimum error yang ditentukan(Soares, 2016).

Algoritma propagasi balik dapat dibagi ke dalam dua bagian:

1. Algoritma pelatihan

Algoritma pelatihan terdiri dari tiga tahap, yaitu: tahap propagasi maju, tahap propagasi mundur, dan tahap perubahan bobot.

2. Algoritma aplikasi

Algoritma aplikasi hanya menggunakan tahap umpan maju saja.

Algoritma pelatihan untuk jaringan dengan satu layer tersembunyi (dengan fungsi aktivasi sigmoid biner) adalah sebagai berikut :

Langkah 0: Inisialisasi semua bobot dengan bilangan acak kecil.

Langkah 1: Jika kondisi penghentian belum terpenuhi, lakukan langkah 2-9.

Langkah2: Untuk setiap pasangan data pelatihan, lakukan langkah 3-8.

Fase I: Propagasi maju

Langkah 3: Tiap unit masukan menerima sinyal dan meneruskannya ke unit tersembunyi di atasnya.

Langkah 4: Hitung semua keluaran di unit tersembunyi

$$
\begin{array}{r}
z_{j} \quad(j=1,2, \ldots, p) . \\
z_{-} \text {net }_{j}=v_{j o}+\sum_{i=1}^{n} x_{i} v_{j i} \\
z_{j}=f\left(z_{n e t_{j}}\right)=\frac{1}{1+e^{-z_{-} \text {net }_{j}}}
\end{array}
$$

Langkah 5: Hitung semua keluaran jaringan di unit keluaran $y_{k} \quad(k=1,2, \ldots, m)$.

$$
\begin{aligned}
& y_{-} n e t_{k}=w_{k o}+\sum_{j=1}^{p} z_{j} w_{k j} \\
& y_{k}=f\left(y_{-} n e t_{k}\right)=\frac{1}{1+e^{-y_{-} n e t_{k}}}
\end{aligned}
$$

Fase II: Propagasi mundur
Langkah 6: Hitung faktor kesalahan $\delta$ unit keluaran berdasarkan kesalahan di setiap unit keluaran $y_{k}(k=1,2, \ldots, m)$.

$\delta_{k}=\left(t_{k}-y_{k}\right) f^{\prime}\left(y_{-} n e t_{k}\right)=\left(t_{k}-y_{k}\right) y_{k}\left(1-y_{k}\right)$

$\delta_{k}$ merupakan unit kesalahan yang akan dipakai dalam perubahan bobot lapisan di bawahnya (langkah7) Hitung suku perubahan bobot $w_{k j}$ (yang akan dipakai nanti untuk merubah bobot $w_{k j}$ ) dengan laju percepatan $\alpha$.

$$
\begin{aligned}
& \Delta w_{k j}=\alpha \delta_{k} z_{j} \\
& k=1,2, \ldots, m \\
& j=0,1, \ldots, p
\end{aligned}
$$

Langkah 7: Hitung faktor kesalahan $\delta$ unit tersembunyi berdasarkan kesalahan di setiap unit tersembunyi $z_{j}(j=1,2, \ldots, p)$.

$$
\delta \_n e t_{j}=\sum_{k=1}^{m} \delta_{k} w_{k j}
$$

Faktor $\delta$ unit tersembunyi :

$$
\delta_{j}=\delta \_n e t_{j} f^{\prime}\left(z_{-} n e t_{j}\right)=\delta_{-} n e t_{j} z_{j}\left(1-z_{j}\right)
$$

Hitung suku perubahan bobot $v_{j i}$ (yang akan dipakai nanti untuk merubah bobot $v_{j i}$ )

$$
\begin{aligned}
& \Delta v_{j i}=\alpha \delta_{j} x_{i} \\
& j=1,2, \ldots, p \\
& i=0,1, \ldots, n
\end{aligned}
$$

Fase III : Perubahan bobot

Langkah 8: Hitung semua perubahan bobot Perubahan bobot garis yang menuju ke unit keluaran:

$$
\begin{aligned}
& w_{k j}(\text { baru })=w_{k j}(\operatorname{lama})+\Delta w_{k j} \\
& (k=1,2, \ldots, m ; j=0,1, \ldots, p)
\end{aligned}
$$

Perubahan bobot garis yang menuju ke unit tersembunyi

$$
\begin{aligned}
& v_{j i}(\text { baru })=v_{j i}(\operatorname{lama})+\Delta v_{j i} \\
& (j=1,2, \ldots, p ; i=0,1, \ldots, n)
\end{aligned}
$$

Setelah pelatihan selesai dilakukan, jaringan dapat dipakai untuk pengenalan pola. Dalam hal ini, hanya propagasi maju (langkah 4 dan 5) saja yang dipakai untuk menentukan keluaran jaringan. Hasil pengaktif unit-unit pada lapisan keluaran merupakan keputusan dari jaringan saraf tiruan (Siang, 2009).

\section{PEMBAHASAN}

Pada pembahasan ini, penulis akan menjelaskan proses dalam melakukan prediksi jumlah produksi air dengan menggunakan algoritma backpropagation. Langkah yang dilakukan oleh penulis adalah proses 
menganalisa data untuk digunakan dalam membangun jaringan. Berikut data yang digunakan dalam proses peramalan dapat dilihat pada tabel 1 :

Tabel 1. Data Rekap Produksi AIR PDAM

\begin{tabular}{c|c|c|c|c|c|}
\hline Jenis & $\mathbf{2 0 1 4}$ & $\mathbf{2 0 1 5}$ & $\mathbf{2 0 1 6}$ & $\mathbf{2 0 1 7}$ & $\mathbf{2 0 1 8}$ \\
\hline $\begin{array}{c}\text { Rumah } \\
\text { Tangga }\end{array}$ & 5174 & 5096 & 5185 & 5410 & 5556 \\
\hline Wsata & - & - & - & - & - \\
\hline sosial & 50 & 33 & 53 & 52 & 53 \\
\hline Umum & 19 & 8 & 11 & 11 & 12 \\
\hline Industri & 3 & 3 & 3 & 3 & 3 \\
\hline Instansi & 98 & 93 & 93 & 95 & 129 \\
\hline Pelabuhan & - & - & - & - & - \\
\hline Jumlah & - & - & - & - & - \\
\hline $\begin{array}{c}\text { Air } \\
\text { produksi }\end{array}$ & 1703247 & 1641701 & 1746728 & 1894222 & 2002567 \\
\hline air Terjual & 696752 & 956824 & 959533 & 1074916 & 1177201 \\
\hline Kebocoran & 590100 & 54741 & 610055 & 661919 & 657271 \\
\hline
\end{tabular}

Dari data rekap produksi diatas, penulis menganalisa data tersebut yang nantinya akan dilanjutkan pada penentuan variabel dalam proses peramalan. Variabel yang digunakan dimulai dari pemakaian yang terjadi pada periode tahun dilihat dari pemakaian Rumah Tangga, Badan Sosial, Umum, Industri, Dan Instansi Pemerintah. Berikut tabel variabel jaringan yang digunakan pada tabel 2 :

Tabel 2. Variabel Jaringan

\begin{tabular}{|c|c|c|c|c|c|}
\hline $\mathbf{X 1}$ & $\mathbf{X 2}$ & $\mathbf{X 3}$ & $\mathbf{X 4}$ & $\mathbf{X 5}$ & $\mathbf{T}$ \\
\hline 5174 & 50 & 19 & 3 & 98 & 696752 \\
\hline 5096 & 33 & 8 & 3 & 93 & 956824 \\
\hline 5185 & 53 & 11 & 3 & 93 & 959533 \\
\hline 5410 & 52 & 11 & 3 & 95 & 1074916 \\
\hline 5556 & 53 & 12 & 3 & 129 & 1177201 \\
\hline
\end{tabular}

Setelah variabel jaringan ditentukan, maka proses penelitian dilanjutkan pada proses algoritma backpropagation. Proses ini perlu dilakukannya transformasi data. Selain itu juga terkait fungsi aktivasi yang diberikan yaitu sigmoid biner.

Fungsi sigmoid adalah fungsi asimtotik (tidak pernah mencapai 0 ataupun 1), maka transformasi data dilakukan pada interval yang lebih kecil yaitu $[0.1 ; 0.8]$, ditunjukkan dengan persamaan:

$$
X^{\prime}=\frac{0.8(x-a)}{b-a}+0.1
$$

Dengan (Sutojo, T, dkk, 2011) :

$0.8=$ Ketetapan

$x=$ Nilai data $\mathrm{ke}-n$

$b=$ Nilai data tertinggi (data tertinggi dari setiap input)

$a=$ Nilai data terendah (data terendah dari setiap input)
Dengan memasukan setiap data pada varibel kedalam persamaan rumus transformasi data, maka hasil perubahan transformasi yang dihasilkan dapat dilihat pada tabel 3. Berikut hasil transformasi data yang sudah dilakukan dapat dilihat pada tabel dibawah ini :

Tabel 3. Data Hasil Transformasi

\begin{tabular}{|c|c|c|c|c|c|}
\hline $\mathbf{X 1}$ & $\mathbf{X 2}$ & $\mathbf{X 3}$ & $\mathbf{X 4}$ & $\mathbf{X 5}$ & $\mathbf{T}$ \\
\hline 0.1865 & 0.6666 & 0.9 & 0.9000 & 0.2111 & 0.0999 \\
\hline 0.1000 & 0.1000 & 0.1000 & 0.9000 & 0.1000 & 0.4809 \\
\hline 0.1987 & 0.7666 & 0.3181 & 0.9000 & 0.1000 & 0.4848 \\
\hline 0.4484 & 0.7333 & 0.3181 & 0.9000 & 0.1444 & 0.6539 \\
\hline
\end{tabular}

Sesudah didapatkan data yang akan dilakukan proses peramalan, penulis melanjutkan lagi dalam pembangunan arsitektur jaringan. Arsitektur jaringan dapat dijadikan faktor penting yang akan mempengaruhi hasil penelitian. Arsitektur jaringan ini dibangun dengan menggunakan berbagai macam pola. Berikut arsitektur jaringan yang dibentuk dapat dilihat pada gambar 1 dibawah ini:

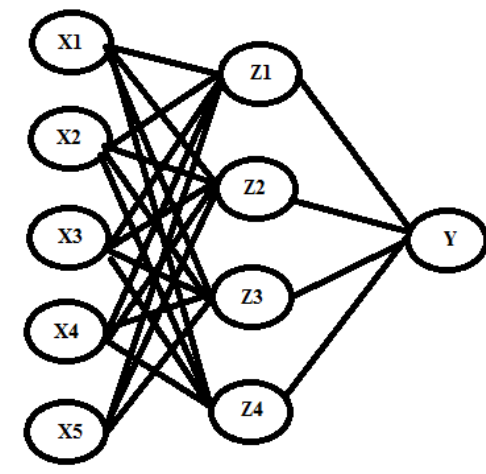

Gambar 1. Arsitektur Jaringan

Pada proses pembentukan pola arsitektur jaringan ini, penulis menggunakan sampel beberapa pola jaringan yang nantinya akan dilakukan proses analisa perbandingan dari pola guna mendapatkan yang terbaik. proses yang dilakukan penulis setelah pembentukan jaringan adalah proses pelatihan dan pengujian jaringan. Proses pelatihan dan pengujian yang dilakukan disini, penulis memanfaatkan software matlab sebagai alat bantu dalam melakukan pelatihan dan pengujian. Bentuk pelatihan dan pengujian yang dilakukan dengan software matlab. 
Tabel 4. Hasil Nilai Pelatihan

\begin{tabular}{|c|c|c|}
\hline Data & Error & Target \\
\hline 1 & -0.0117 & 0.0999941 \\
\hline 2 & -0.0099 & 0.4809285 \\
\hline 3 & -0.032 & 0.4848965 \\
\hline 4 & 0.052 & 0.653901 \\
\hline Jumlah & -0.0016 & 1.7197201 \\
\hline \multicolumn{2}{|c|}{ Mape } & 0.000232596 \\
\hline \multicolumn{2}{|c|}{ \%Mape } & 0.023259599 \\
\hline \multicolumn{2}{|c|}{ Keakuratan } & 99.9767404 \\
\hline
\end{tabular}

Dengan didapatkanya hasil pelatihan dari penggunaan software matlab, peenulis juga akan memberikan hasil bentuk pelatihan dalam tampilan grafik training. Berikut hasil gambar 2 yang memperlihatkan hasil pelatihan :

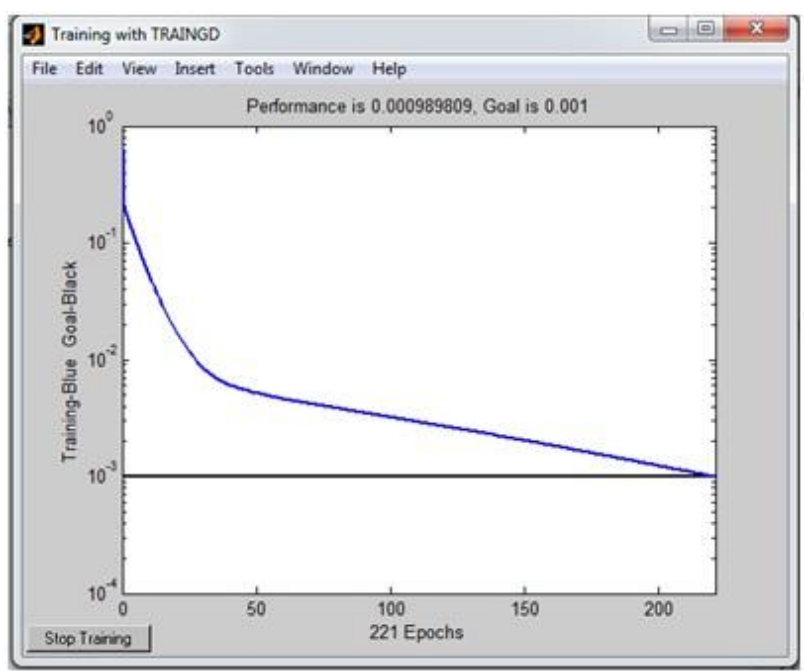

Gambar 2. Grafik Hasil Pelatihan

Proses pelatihan dalam hal ini akn dilajutkan dengan menggunakan pola arsitektur jaringan yang berbeda. Berikut hasil pelatihan dari beberapa sampel yang digunakan dapat dilihat pada tabel 5 dibawah ini :

Tabel 5. Perbandingan Pola Jaringan

\begin{tabular}{|c|l|l|}
\hline \multirow{2}{*}{ Pola arsitektur } & \multicolumn{2}{|c|}{ Nilai Mape } \\
\cline { 2 - 3 } & Pelatihan & Pengujian \\
\hline $5-3-1$ & 0.001090294 & 0.00214237 \\
\hline $5-4-1$ & 0.000232596 & 0.00011739 \\
\hline $5-5-1$ & 0.000828623 & 0.002523888 \\
\hline $5-6-1$ & 0.000436 & 0.00167 \\
\hline $5-7-1$ & 0.001701 & 0.00288 \\
\hline
\end{tabular}

Berdasarkan hasil perbandingan, didapat pola jaringan yang terbaik berada pada pola 5-6-1 yang dilihat dari nilai Mape. Nilai tersebut merupakan nilai Means Percentage Error atau yang bisa dikenal dengan nilai persentasi dari kesalahan. Dengan demikian, maka proses peramalan pada kasus penentuan jumlah produksi air ini mampu dilakukan dengan menggunakan jaringan saraf tiruan dengan menggunaka algoritma backpropagation.

Setelah proses pelatihan selesai, data keluaran yang sudah didapatkan dari pelatihan jaringan yang masih dalam bentuk normalisasi, sehingga mesti dilakukannya proses denormalisasi data yang bertujuan untuk mengembalikan nilai hasil keluaran data yang masih dalam bentuk normalisasi kedalam bentuk data yang sebenarnya, dengan persamaan denormalisasi 13 dibawah :

$$
\begin{aligned}
X^{\prime} & =x\left(x_{\max }-x_{\min }\right)+x_{\min } \\
X^{\prime} & =0.1117(1242933-696756)+696756 \\
& =757583,9709
\end{aligned}
$$

Hasil yang sudah di denormalisasikan ini dapat dijadikan masukan dalam melihat hasil jumlah produksi yang akan terjadi pada periode tahun berikutnya.

\section{KESIMPULAN}

Dari pembahasan penelitian ini, maka kesimpulan dari penelitian ini bahwa, dengan adanya Jaringan Syaraf Tiruan dalam peramalan jumlah produksi air dapat digunakan sebagai input untuk memanajemen jumlah produksi air berdasarkan pengujian yang telah dilakukan. Peramalan pada proses pelatihan dan pengujian jumlah didapatkan pola arsitektur jaringan 5-6-1 dengan akurasi 99.97\%. Kemudian dalam penelitian ini, Hal yang paling diperhatikan adalah saat menentukan Faktor pemilihan variabel jaringan sangat berpengaruh pada ketepatan hasil peramalan jumlah produksi air dan bukan hanya variabel saja, untuk pola arsitekturnya pun juga akan mempengaruhi hasil peramalan.

\section{SARAN}

Pada penelitian yang akan dilanjutkan dalam kajian proses peramalan, penulis menyarankan untuk dapat melakukan pelatihan dan pengujian jaringan dengan menggunakan banyak percobaan pola arsitektur jaringan. Pola arsitektur jaringan ini nantinya akan juga dapat menentukan hasil peramalan sehingga memberikan hasil yang terbaik dari nilai persentasi akurasi hasil peramalan.

\section{DAFTAR PUSTAKA}

Daneswara Jauhari, dkk, 2016, Prediksi Distribusi Air Pdam Menggunakan Metode Jaringan Syaraf Tiruan Backpropagation Di Pdam Kota Malang, Jurnal Teknologi Informasi dan Ilmu Komputer (JTIIK) Vol. 3, No. 2

Dwi Rahayu, dkk, 2018, Implementasi Metode Backpropagation Untuk Klasifikasi Kenaikan Harga Minyak Kelapa Sawit, Jurnal Pengembangan Teknologi Informasi dan Ilmu Komputer, Vol. 2, No. 4. 
Irawan, A. F. 2015. Implementasi Metode Jaringan Syaraf Tiruan Backpropagation Pada Peramalan Kebutuhan Air Pdam Kota Malang. Skripsi, Universitas Brawijaya.

Irwansyah, Edy dan Faisal, Muhammad. 2015. Advanced Clustering: Teori dan Aplikasi. Yogyakarta : Deepublish

Huang and $\mathrm{Z}$. Wu,2017, "Forecasting outpatient visits using empirical mode decomposition coupled with backpropagation artificial neural networks optimized by particle swarm optimization," PLoS ONE, vol. 12, no. 2, pp. 1-18

Muhammad Reza dan Suprayogi, 2017, Prediksi Jangka Waktu Pengiriman Barang Pada PT. Pos Indonesia menggunakan Backpropagation, ogito Smart Journal/VOL. 3/NO. 1

Nabilla Putri Sakinah,dkk, 2018, Prediksi Jumlah Permintaan Koran Menggunakan Metode Jaringan Syaraf Tiruan Backpropagation, Jurnal Pengembangan Teknologi Informasi dan Ilmu Komputer, Vol. 2, No. 7
Nikmah, Nanik Ulfatun. 2014. Prediksi Kebutuhan Air Pdam Berdasarkan Jumlah Pelanggan Menggunakan Al-Alaoui Backpropagation. Skripsi, Universitas Brawijaya.

Soares, F., M., Souza, A., M., F. 2016. Neural Network Programming With Java. Packt Publishing Ltd, Mumbai.

Sutojo, T dkk. (2011). Kecerdasan Buatan. Yogyakarta: Andi Offset.

Yanto, Musli, dkk. 2018. Peramalan Penjualan Pada Toko Retail Menggunakan Algoritma Backpropagation Neural Network, Media Informatika Budidarma, Vol 2, No. 3

Yanto, Musli, dkk. 2015, Analisis Jaringan Syaraf Tiruan Untuk Memprediksi Jumlah Reservasi Kamar Hotel Dengan Metode Backpropagation, Jurnal KomTekInfo Fakultas Ilmu Komputer, Volume 2, No. 1 